\title{
HEIGHT, DIAMETER AND TREE CANOPY COVER ESTIMATION BASED ON UNMANNED AERIAL VEHICLE (UAV) IMAGERY WITH VARIOUS ACQUISITION HEIGHT
}

\author{
MUflihatUl MAGFIROH ISLAMI $^{1)}$, TEDDY RUSLONO ${ }^{1)}$, YUdi SETIAWAN ${ }^{2)}$, ASWIN RAHADIAN ${ }^{3)}$, SAHID \\ AGUSTIAN HUDJIMARTSU ${ }^{4)}$, AND LILIK BUDI PRASETYO ${ }^{2 *}$ \\ ${ }^{1}$ Department of Forest Management, Faculty of Forestry and Environment, IPB University, Academic Ring Road \\ Campus IPB Dramaga, Bogor, Indonesia 16680 \\ ${ }^{2}$ Department of Forest Resources Conservation and Ecotourism, Faculty of Forestry and Environment, IPB University, \\ Academic Ring Road Campus IPB Dramaga, Bogor, Indonesia 16680 \\ ${ }^{3}$ Natural Resources and Environmental Management, IPB University, Campus IPB Baranangsiang, Bogor City, \\ Indonesia 16128 \\ ${ }^{4}$ Department of Informatics Engineering, Faculty of Engineering and Science, Ibn Khaldun University, Jl. Sholeh \\ Iskandar, Bogor, Indonesia 16162 \\ *Email: lbprastdp@apps.ipb.ac.id
}

Accepted Desember 17, 2020 / Approved Januari 05, 2021

\begin{abstract}
The forest inventory technique by applying remote sensing technology has become a new breakthrough in technological developments in forest inventory activities. Unmanned Aerial Vehicle (UAV) imagery with camera sensor is one of the inventory tools that produce data with high spatial resolution. The level of spatial resolution of the image is strongly influenced by the flying height of the UAV for a certain camera's focus. In addition, flight height also affects the acquisition time and accuracy of inventory results, although there is still little research on this matter. The study aims to (a)evaluate the effect of various flying heights on the accuracy of tree height measurements through UAV imagery for every stand age class, (b).estimate the trees diameter and canopy cover for every stand age class. Stand height was estimated using Digital Surface Models (DSM), Digital Terrain Models (DTM) and Orthophoto. DSM and DTM were built by converting orthophoto to pointclouds using the PIX4Dmapper based on Structure From Motion (SFM) on the photogrammetric method to reconstruct topography automatically. Meanwhile, the tree cover canopy was estimated using the All Return Canopy Index (ARCI) formula. The results show that the flight height of 100 meters produces a stronger correlation than the flying height of 80 meters and 120 meters in estimating tree height, based on the high coefficient of determination $\left(R^{2}\right)$ and the low root mean square error (RMSE) value. In addition, tree canopy estimation analysis using ARCI has a maximum difference of $9.8 \%$ with orthophoto visual delineation.
\end{abstract}

Key words: canopy height model (CHM), digital surface models (DSM), digital terrain models (DTM), forest inventory, UAV image

\section{INTRODUCTION}

Forest inventory is systematic activity in the forestry sector used in determining the potential of a forest area through the measurement of several basic variables associated with the condition of forest stand such as diameter at breast height ( dbh), tree height, and crown area of each tree. The measurement of these parameters is important to the determination of information related to forest potential such as the stand volume and density as well as the quality of the land to ensure optimum growth (Sumarna 2008; Kusnadi 2016).

The information on the potential of a forest is usually obtained through direct inventory in the field. The process has been improved in recent years based on the development of some aspects of science, especially statistics. Inventory used to be conducted through census of tree stands in the forest was replaced by sampling techniques (Lynch \& Rusyidi 1999), however it is still require a lot of man power and costly (Bottalico et al. 2017).
The limitations and inefficiency of manual forest inventory have spurred experts to develop other techniques such as the application of remote sensing technology to monitor the appearance of landscapes on earth through the use of aerial photographs (Pôças et al. 2011). This is, however, gradually being replaced by satellite imagery since the 1980s which has also become a very popular method for monitoring landscapes and natural resources in different ecosystems, including forest areas ( $\mathrm{Gu}$ et al. 2007). Meanwhile, recently photographs of earth landscapes, mainly forest areas, are presently being taken using unmanned aerial vehicles or UAV.

UAVs are used without any obstruction of cloud as always found with aerial photographs and satellite imagery and this makes the data collection process to be more effective, efficient, and accurate (Zarco-Tejada et al. 2014). They are also capable of producing data with a high spatial resolution at a lower cost and with ease (Klemas \& Victor 2015) and this makes their application in forestry sector to be good and appropriate (Ye et al. 
2019). Moreover, UAV imagery has also been reported to be applicable in separate analysis of individual trees and stand density as part of remote sensing technology (Mweresa et al. 2017).

The use of UAV provides several advantages to the production of detailed aerial photographs and this is observed from the ability to acquire image based on flight variable settings. Several studies have been conducted particularly on tree detection analysis as part of forest inventory activities using UAV data by many experts in the forestry sector. For example, Birdal et al. (2017) measured plant height and canopy identification using UAV data obtained from aircraft flying at 150 meters above the ground, Birdal et al. (2017) and Ok \& Ozdarici (2017) used 140 m, Mu et al. (2018) flew UAV at $30 \mathrm{~m}$ while Rokhmana (2015) used the technology to support accuracy in agricultural mapping at an altitude of $160 \mathrm{~m}$.

The variation of flying height is useful in obtaining a representative image with a high degree of accuracy and mapping at a detailed scale for object identification, especially in the forestry sector (Mu et al. 2018). Previous studies have used UAV data for forest inventory activities at different height but further research needs to be conducted on this concept. Therefore, this research aimed to evaluate the effect of flight variables on the accuracy of tree measurements through UAV imagery.

\section{RESEARCH METHOD}

This research was conducted in February 2020 at West Java and Banten State-Owned Forestry Company, precisely at the Ciamis Forest Management Unit (KPH), with the focus on two sections of the Forest Management Unit (BKPH) including Banjar Selatan BKPH within Pamarican RPH and Pangandaran BKPH in RPH within Pangandaran RPH area. The administrative area of Ciamis KPH is located at 7²41'5 "PS and 108 $45^{\prime} 25^{\prime \prime}$ East Longitude as shown in Figure 1.

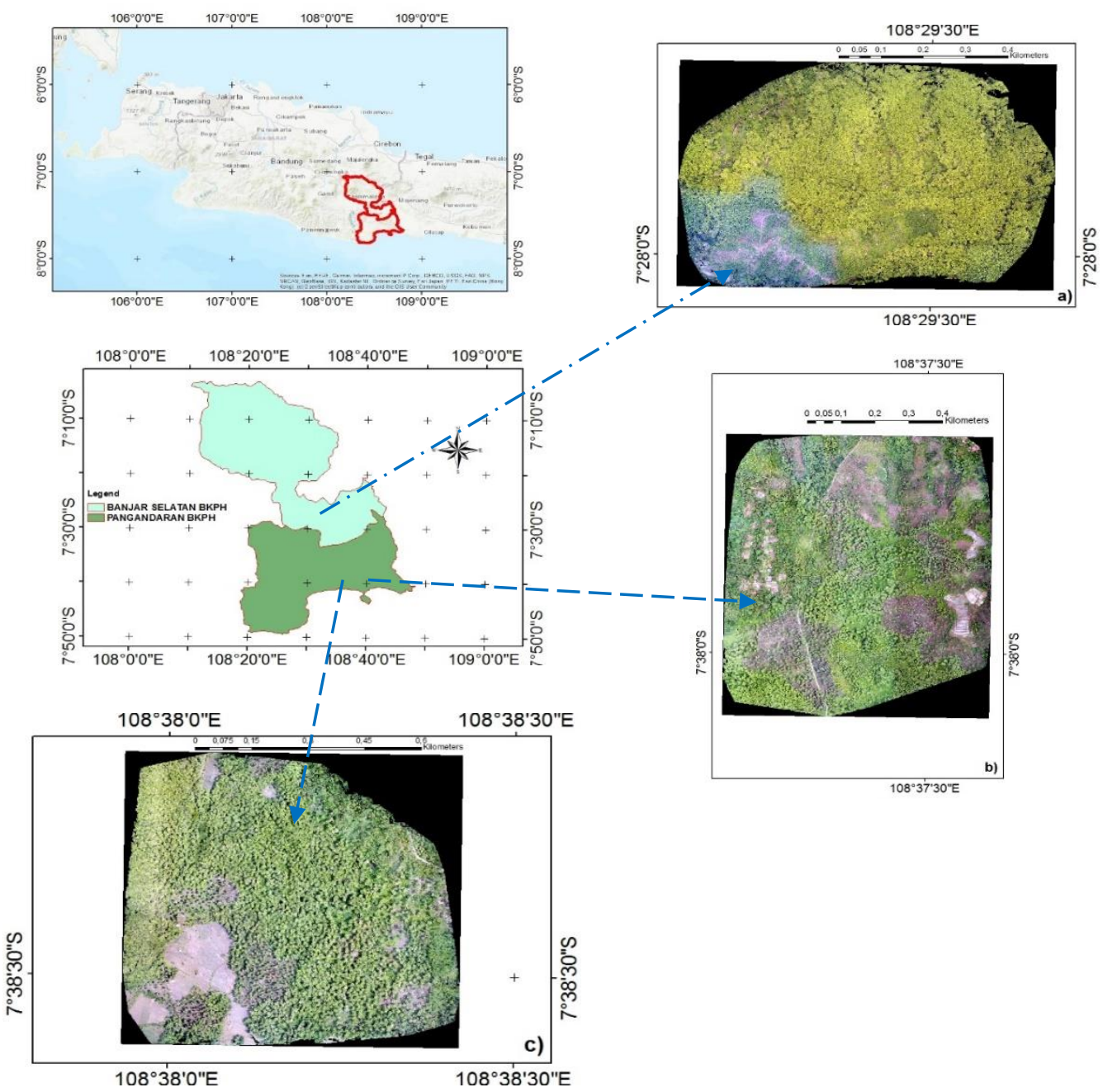

Figure 1 Research sites, Plot location in the Ciamis-Indonesia. Image resources a) age class IV; b) age class VI, and c) age class VIII (Imageries provided from drone camera shots and mosaicking) 
The research procedure includes (1) Flight Plan Preparation (2) GCP installation (3) Tree Measurement (4) UAV Flight Technique (5) Ortho Photo Mosaic (6) Canopy height model (7) Canopy Cover Model (8)
Statistical Analysis. Flight Plan Preparation by making AOI for the flight path and determining flight variables as presented in Table 1 and illustration of flying a drone in Figure 2.

Table 1 Pre-flight variable design plans based on age class representation

\begin{tabular}{lrrr}
\hline Flight Variables & \multicolumn{2}{c}{ Age class IV Treatment } \\
\hline flying above the ground & 80 & 100 & 120 \\
Camera angle & $90^{\circ}$ & $90^{\circ}$ & $90^{\circ}$ \\
Overlap, sidelap & 80,70 & 80,70 & 80,70 \\
\hline Flight Variables & & Age class VI Treatment & 120 \\
\hline flying above the ground & 80 & 90 & $90^{\circ}$ \\
Camera angle & $90^{\circ}$ & 80,70 & 80,70 \\
Overlap, sidelap & 80,70 & & Age class VIII Treatment \\
\hline Flight Variables & 80 & 100 & 120 \\
flying above the ground & $90^{\circ}$ & $90^{\circ}$ & $80^{\circ}$ \\
Camera angle & 80,70 & 80,70 & 80,70 \\
Overlap, sidelap & &
\end{tabular}

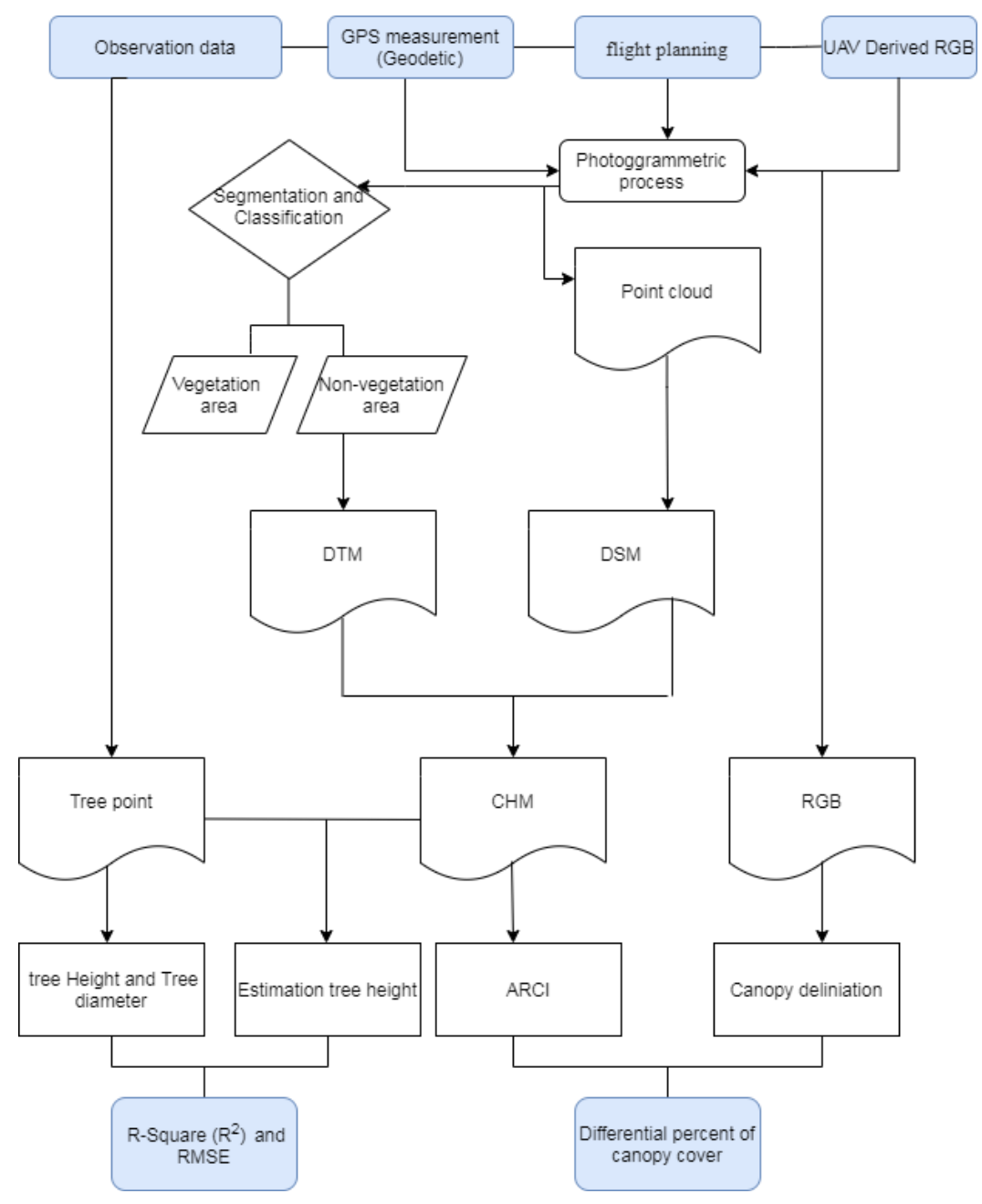

Figure 1 Flow Chart of the Analysis 
Flight plan preparation was important before shooting and initiated by making AOI for the flight path using different scenarios presented in Table 1 and flight variables such as the flying height to evaluate the effect of using UAVs on the accuracy of tree measurements. The variables of overlap, side lap, and camera angles were normalized at 80,70 , and $90^{\circ}$ respectively while the flying height was varied at 80,100 , and $120 \mathrm{~m}$. The vehicle used for the shooting was a DJI Phantom 4 Quadcopter Drone having a camera with lens magnification of $5.2 \mathrm{~mm}$ and a resolution of 12 Megapixels. Furthermore, Drone Deploy with an android-based application was used to estimate flight duration and the number of batteries required for several designs of flight treatment.

Field survey was conducted in three specific areas of West Java and Banten State-Owned Forestry Company using existing age classes which are 4, 6, and 8 with the same sampling treatment applied to each of them. GCP installation was conducted by spreading out the surveyed pre-mark signs which are $2 \times 2$ meters in size as presented in Figure 3. Moreover, each GCP coordinate was obtained using Geodetic GPS with conditions and installation process shown in Figures 3(ii) and (iii) respectively. They were designed to be evenly distributed at the research location while another point was connected by the National Geodetic Control Network (JKGN). Meanwhile, the evenly distributed premark and open area are indicated in Figure 3(i) and this is considered important due to its effects on the accuracy of UAV photogrammetry images (Carricondoa et al. 2018). the pre-marks position were measured by Trimble Differential GPS based on the closest National Geodetic Control Network (JKGN), a benchmark position of Geospatial Information Agency/Badan Informasi Geospasial (BIG) (Figure 3).

The process involved the selection of 30 tree samples with easy accessibility and observation through orthophoto results. The trees position were also marked with Garmin's handheld GPS with three replication and imported using ESRI Arcgis. Tree measurements include tree diameter, each measurement using a hypsometer and a phiband.

The UAV is flown at a fixed altitude from the highest point and does not follow the terrain, taking into account site conditions and safety. The flight technique follows the flight design according to Table 1.The vertical section is presented in Figure 4.

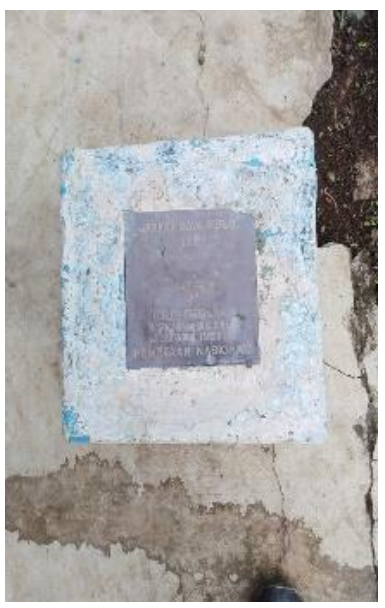

(i)

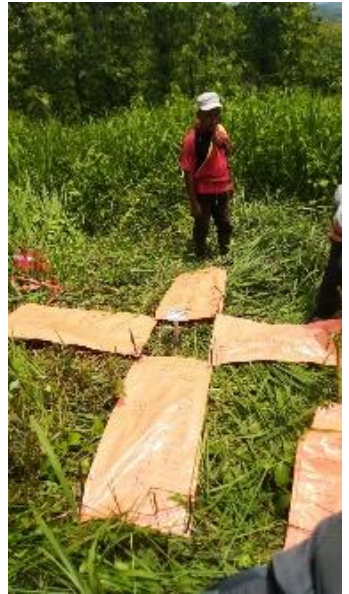

(ii)

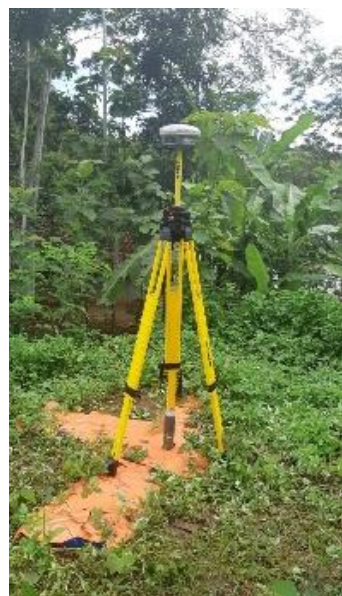

(iii)

Figure 2 (i) geodetic tie point, (ii) pre-mark laying activities, (iii) measurement of pre-mark points using Geodetic GPS

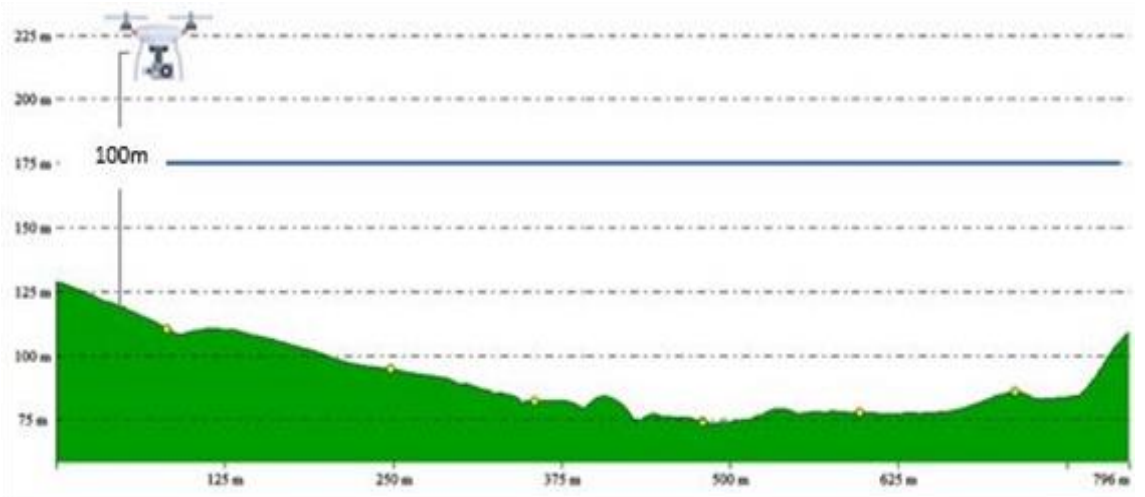

Figure 3 Ilustrasi of trying a drone at $100 \mathrm{~m}$ above the forest 
Ortho Photo Mosaic Process using PIX4DMapper software to produce an orthophoto with an accurate result which was assisted by placing the GCP point as a georectification. Moreover, the image processing activities consisted of alignment, building dense cloud, texturing, orthomosaicking, DSM, and DTM to produce orthophoto.

Individual tree detection was through data and images processed using automatic Structure For Motion (SFM) method with PIX4Dmapper built through point clouds in the form of DSM and DTM (Eltner dan Sofia 2020), as indicated in the flow chart of Figure 2. Moreover, the tree height was obtained using Equation 1 while the location of the treetop was based on the maximum pixel value of the tree position in each kernel extracted from the terrestrial measurement..

$$
\mathrm{CHM}=\mathrm{DSM}-\mathrm{DTM}
$$

Where: CHM = Canopy Height Model, DSM = Digital Surface Model, DTM= Digital Terrain Model

Estimation of canopy cover from RGB imagery drones involved the identification of canopy cover percentage through the DSM computed with DTM (CHM) percentage and later compared with the results obtained from visual identification using orthophoto data. Meanwhile, the percentage of the crown cover area was calculated using a formula of All Return Cover Index (ARCI) (Ma et al. 2017) as shown in the following equation.

$$
\text { ARCI }=\frac{\sum \text { Allcanopy }}{\sum \text { AllTotal }} \times 100 \%
$$

Where: $\Sigma$ Allcanopy $=$ total return to canopy, $\Sigma$ AllTotal $=$ sum of all return

Statistical Analysis, The accuracy of the regression model was determined using the coefficient of determination (R2) and Root Mean Square Error (RMSE) which are formulated according to Walpole (1995) as follows:

Determination coefficient $\left(\mathrm{R}^{2}\right)$; This was used to test the strength of a dependent variable as explained by the estimator variable. The $\mathrm{R}^{2}$ value ranges from 0 to 1 with those closer to 1 indicating a stronger effect of the estimator variable on the dependent variable while those closer to 0 indicate a weaker effect. The value is, however, calculated using the following Equation 3. Root Mean Square Error (RMSE), This is the level of error in a prediction with the smaller values close to 0 showing more accurate prediction and usually calculated using the following equation 4 .

$$
R^{2}=1-\frac{\Sigma\left(y_{i}-\vec{y}\right)^{2}}{\Sigma\left(\left(y_{i}-\vec{y}\right)^{2}\right.}
$$

Where: $\hat{y}_{=}$estimated value of $\mathrm{y}, \bar{y}=$ average value of $\mathrm{y}$

RMSE $=\sqrt{\frac{\sum\left(y_{i}-\widehat{y}^{2}\right.}{n}}$

Description: $\mathrm{N}=$ number of trees, $y_{i}=$ height of the observation tree $(\mathrm{m}) \hat{y}=$ Estimated tree height $(\mathrm{m})$

\section{RESULT AND DISCUSSION}

\section{GSD and Tree Position}

Acquisition of images with various altitudes results in different Ground Sample Distance (GSD), the higher the flight, the bigger the GSD. GSD reflects the level of image accuracy, therefore the smaller the GSD the smaller the pixel size (Table 2).

However, the accuracy of tree position estimation is not in line with GSD. The overlay between tree points (30 points) and the orthophoto of UAV are presented in Figure 5. From the figure, it can be seen visually that the position of the tree that is close to the conditions in the field and in accordance with the treetops is an orthophoto

\begin{tabular}{|c|c|c|c|}
\hline Age class & Area (ha) & Flying height (m) & GSD (cm/pixel) \\
\hline \multirow{3}{*}{ IV } & \multirow{3}{*}{11.552} & 80 & $4,17 \mathrm{~cm} /$ pixel \\
\hline & & 100 & $4.77 \mathrm{~cm} /$ pixel \\
\hline & & 120 & $5.65 \mathrm{~cm} /$ pixel \\
\hline \multirow{3}{*}{ VI } & \multirow{3}{*}{49.048} & 80 & $2.91 \mathrm{~cm} /$ pixel \\
\hline & & 100 & $3.53 \mathrm{~cm} /$ pixel \\
\hline & & 120 & $4.02 \mathrm{~cm} /$ pixel \\
\hline \multirow{3}{*}{ VIII } & \multirow{3}{*}{45.181} & 80 & $3.59 \mathrm{~cm} / \mathrm{pixel}$ \\
\hline & & 100 & $4.21 \mathrm{~cm} / \mathrm{pixel}$ \\
\hline & & 120 & $4.68 \mathrm{~cm} /$ pixel \\
\hline
\end{tabular}
taken at a flying height of 100 meters in all age classes.

Table 2 GSD Value and Total GCP used in the field 


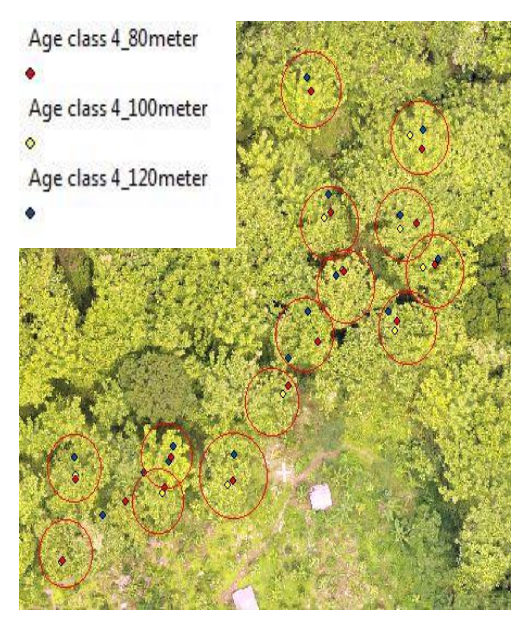

(i)

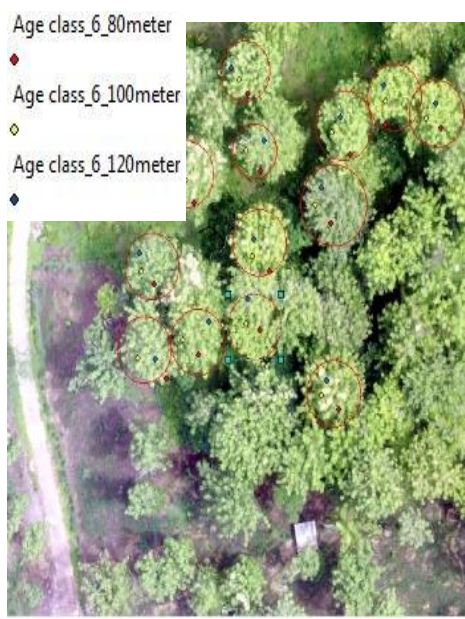

(ii)

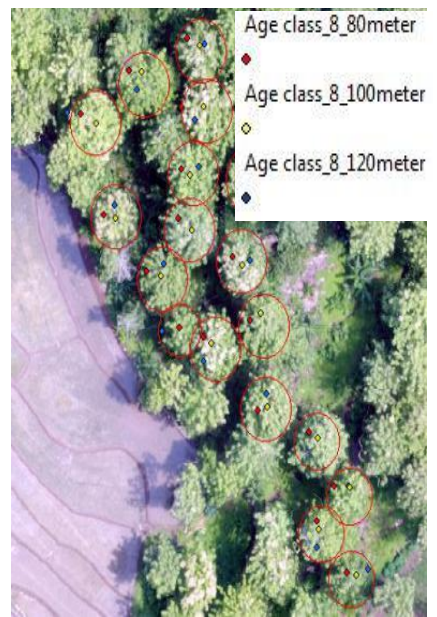

(iii)

Figure 4 Tree points position : (i) age class IV, (ii) age class VI, and (iii) age class VIII of each flying height

\section{Tree height}

The image acquisition was obtained from UAV used PIX4DMapper with SFM algorithm. The algorithm is automatically capable of generating three-dimensional data from two-dimensional images, in which the processing is inexpensive and does not require much expert supervision when compared to conventional aerial photographs (Micheletti et al. 2019). In addition, the algorithm is able to display field geometry, point cloud, and image position information to provide alternative attribute information in modeling the earth's surface. Data processing by using DTM and DSM data produced an average tree height by extracting the data into CHM (Equation 1) so, the estimated tree height was according to the research site for each age class. Linear regression between field measurement of tree height and its estimation based on orthophoto are presented Table 3 to Table 5 and Figure 6 . The analysis was then continued by estimating the diameter using estimated tree height. The results of regression analysis are presented in Tables $6-$ Table 8 and Figure 6.

Result of linear regression analysis above indicated R2 value of each flying height for each age class. The correlation value had a strong relationship between height of observation tree (T.obs) and estimated tree height (T.est) of UAV image for each flying height, mainly at the $100 \mathrm{~m}$ flying height, such as in age class VI with flying height $100 \mathrm{~m}, \mathrm{R} 2$ value was 0.935 or $93.5 \%$ which meant the T.Obs variable was explained by $93.5 \%$ by T.est variable. In other hand, the remaining $6.5 \%$ was explained by variables other than T.est. The linear equation obtained was the estimated height (T.est) = $0.767+0.965$ Observation height (T.obs) meant an increase of 1 meter in the observation height had a positive effect on the estimated height of 0.965 . Overall, the flying height of 100 meters had a strong relationship between the observation height and the estimated height. Likewise, the correlation value between the diameter (D.obs) and the estimated height (T.obs) indicated a high R2. This was confirmed by RMSE value for $100 \mathrm{~m}$ flying height classified as small or close to 0 when compared to $80 \mathrm{~m}$ and $120 \mathrm{~m}$ flying height which had RMSE values ranging from 0.9 to 1 . In general, the result accuracy for $100 \mathrm{~m}$ flying height was acceptable and indicated that the method was feasible to detect tree height and tree diameter by using tree height through UAV imagery. Factors that affected the high coefficient of determination were shooting time (Table 9 and Figure 7) and premark distribution. Most likely that the time difference of acquisition caused the variation of the coefficient (Table 9).

Table 3 Linier regersion between field measurement and estimation tree heightt at $80 \mathrm{~m}$ flying height

\begin{tabular}{|c|c|c|c|c|c|}
\hline Flying Height & $\begin{array}{l}\text { Age class/ } \\
\text { Number of trees sample }\end{array}$ & Korelasi & Model Regresi Linier & $\mathrm{R}^{2}$ & RMSE \\
\hline \multirow{3}{*}{80} & $4 / 30$ & T.obs-T.est & $y=2.75+0.839 x$ & 0.727 & 1.175 \\
\hline & $6 / 30$ & T.obs-T.est & $y=4.06+0.850 x$ & 0.769 & 1.086 \\
\hline & $8 / 30$ & T.obs-T.est & $y=4.57+0.834 x$ & 0.801 & 1.109 \\
\hline
\end{tabular}


Table 4 Linier regersion between field measurement and estimation tree heightt at $100 \mathrm{~m}$ flying height

\begin{tabular}{cccccc}
\hline \multirow{2}{*}{ Flying Height } & \multicolumn{1}{c}{$\begin{array}{c}\text { Age class/ } \\
\text { Number of trees sample }\end{array}$} & Korelasi & Model Regresi Linier & R $^{2}$ & RMSE \\
\hline \multirow{3}{*}{100} & $4 / 30$ & T.obs-T.est & $\mathrm{y}=-0.29+1.04 \mathrm{x}$ & 0.877 & 0.889 \\
\cline { 2 - 6 } & $6 / 30$ & T.obs-T.est & $\mathrm{y}=0.767+0.965 \mathrm{x}$ & 0.935 & 0.592 \\
\cline { 2 - 6 } & $8 / 30$ & T.obs-T.est & $\mathrm{y}=2.19+0.945 \mathrm{x}$ & 0.903 & 0.831 \\
\hline
\end{tabular}

Table 5 Linier regersion between field measurement and estimation tree heightt at $120 \mathrm{~m}$ flying height

\begin{tabular}{|c|c|c|c|c|c|}
\hline Flying Height & $\begin{array}{l}\text { Age class/ } \\
\text { Number of trees sample }\end{array}$ & Korelasi & Model Regresi Linier & $\mathrm{R}^{2}$ & RMSE \\
\hline \multirow{3}{*}{120} & $4 / 30$ & T.obs-T.est & $y=0.83+0.916 x$ & 0.788 & 1.086 \\
\hline & $6 / 30$ & T.obs-T.est & $y=4.92+0.796 x$ & 0.777 & 0.994 \\
\hline & $8 / 30$ & T.obs-T.est & $y=1.73+0.917 x$ & 0.871 & 0.943 \\
\hline
\end{tabular}

Table 6 Linear regression between field measurement of tree diameter and tree height estimation at a flying height of 80 $\mathrm{m}$

\begin{tabular}{cccccc}
\multirow{2}{*}{ Flying Height } & $\begin{array}{c}\text { Age class/ } \\
\text { Number of trees sample }\end{array}$ & Korelasi & Model Regresi Linier & R $^{2}$ & RMSE \\
\hline \multirow{3}{*}{80} & $4 / 30$ & D.obs-T.est & $\mathrm{y}=6.53+0.492 \mathrm{x}$ & 0.644 & 1.343 \\
\cline { 2 - 6 } & $6 / 30$ & D.obs-T.est & $\mathrm{y}=10.9+0.255 \mathrm{x}$ & 0.685 & 1.268 \\
\cline { 2 - 7 } & $8 / 30$ & D.obs-T.est & $\mathrm{y}=7.98+0.346 \mathrm{x}$ & 0.802 & 1.109 \\
\hline
\end{tabular}

Table 7 Linear regression between field measurement of tree diameter and tree height estimation at a flying height of $100 \mathrm{~m}$

\begin{tabular}{|c|c|c|c|c|c|}
\hline Flying Height & $\begin{array}{c}\text { Age class/ } \\
\text { Number of trees sample }\end{array}$ & Korelasi & Model Regresi Linier & $\mathrm{R}^{2}$ & RMSE \\
\hline \multirow{3}{*}{100} & $4 / 30$ & D.obs-T.est & $y=4.60+0.602 x$ & 0.757 & 1.253 \\
\hline & $6 / 30$ & D.obs-T.est & $y=7.84+0.307 x$ & 0.933 & 0.600 \\
\hline & $8 / 30$ & D.obs-T.est & $y=5.94+0.394 x$ & 0.913 & 0.781 \\
\hline
\end{tabular}

Table 8 Linear regression between field measurement of tree diameter and tree height estimation at a flying height of $120 \mathrm{~m}$

\begin{tabular}{lcccccc}
\hline \multirow{2}{*}{ Flying Height } & \multicolumn{2}{c}{$\begin{array}{c}\text { Age class/ } \\
\text { Number of trees sample }\end{array}$} & Korelasi & Model Regresi Linier & $\mathrm{R}^{2}$ & RMSE \\
\hline \multirow{3}{*}{120} & $4 / 30$ & D.obs-T.est & $\mathrm{y}=5.08+0.533 \mathrm{x}$ & 0.685 & 1.323 \\
\cline { 2 - 7 } & $6 / 30$ & D.obs-T.est & $\mathrm{y}=10.8+0.250 \mathrm{x}$ & 0.759 & 1.033 \\
\cline { 2 - 7 } & $8 / 30$ & D.obs-T.est & $\mathrm{y}=4.64+0.395 \mathrm{x}$ & 0.943 & 0.624 \\
\hline
\end{tabular}

Table 9 Photoshoot time

\begin{tabular}{c|c|c|r}
\hline \multirow{2}{*}{ Age class } & \multicolumn{2}{|c}{ Photoshoot time (IWT) for each flying height (meter) } \\
\cline { 2 - 4 } & 80 meters & 100 meters & 120 meters \\
\hline \multirow{2}{*}{ IV } & $12.46-12.59$ & $11.47-11.54$ & $11.08-11.13$ \\
\cline { 2 - 4 } VI & $11.11-12.22$ & $10.31-11.03$ & $09.43-10.08$ \\
\cline { 2 - 4 } & $11.00-12.15$ & $10.15-10.47$ & $09.43-10.02$ \\
\hline
\end{tabular}




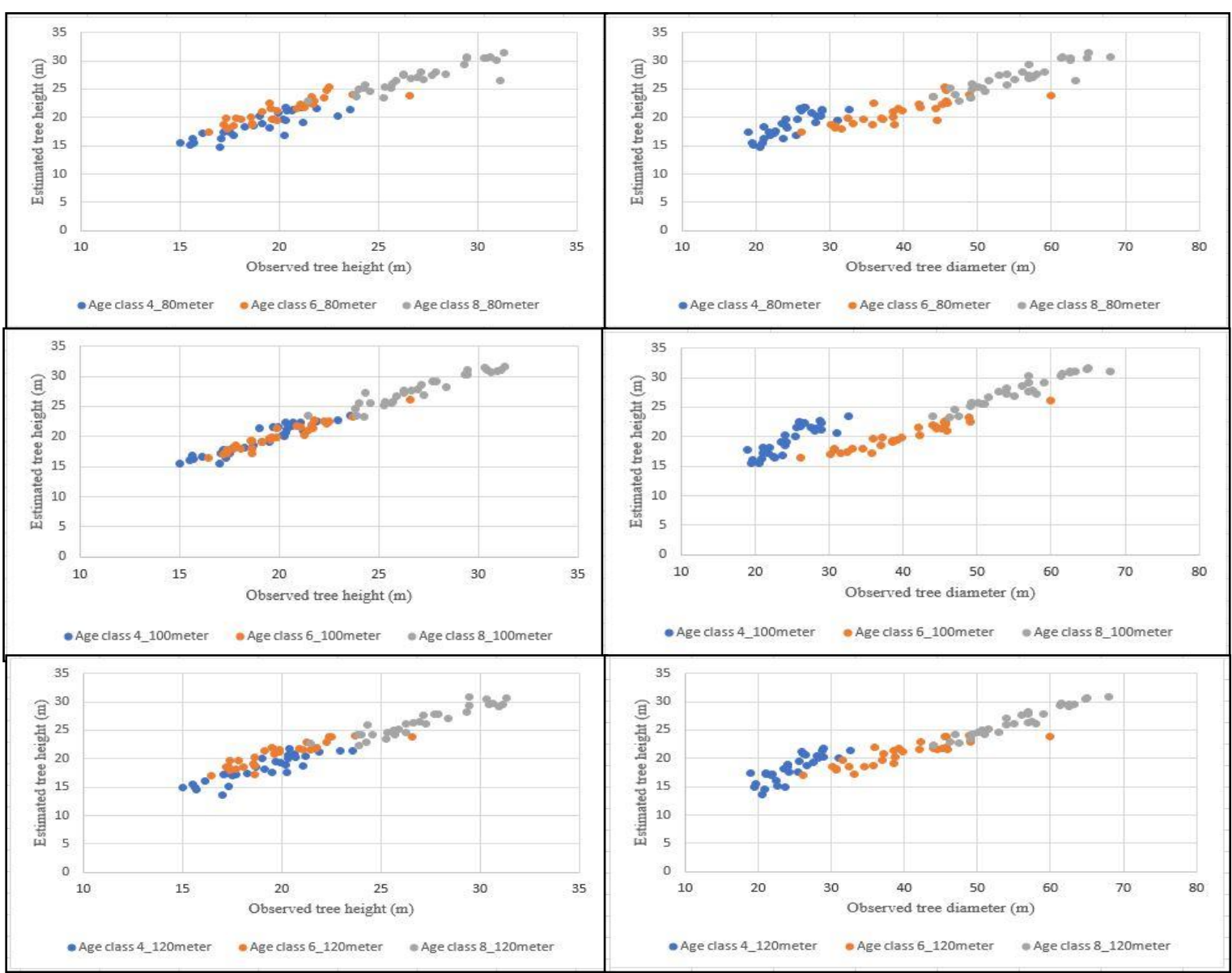

Figure 5 Linear regression model between the height of the observation tree and the estimated tree height presented in the graph on the left and the linear regression model between the diameter of the observation tree and the height of the estimated tree shown in the graph on the right

\section{Canopy Cover Density}

The DSM and DTM data were generated on the site using PIX4Dmapper software and the results extracted produced CHM data which was used as the information on vegetation height. The value obtained from one of the age class produced a minimum value of -2.6828 and a maximum value of 23.0264 on the raster as shown in Figure 8(i). The maximum value in CHM data was close to the average tree height calculated based on the terrestrial results in age class 4 which was observed to be between 15-20 meters and the minus on the value occurred due to an error associated with the presence of noise or lack of vegetation on the ground. Moreover, the height of the displayed area was different in color gradations ranging from light red to dark green with the red indicating sloping areas while green represents high elevation areas as indicated in Figure 8(i).

The canopy area density was estimated using the ARCI formula method by comparing the CHM and orthophoto data in Table 10. Meanwhile, one of the results of the classification processing from $\mathrm{CHM}$ data is presented in Figure 8 (i) while the result of the visual digitization of orthophoto data at a flying height of 100 meters is presented in Figure 8 (iii). CHM data were also analyzed by separating the tree canopy and canopy gaps into different classes (Banu et al. 2017) to determine the density of the canopy area using the ARCI method.

The analysis conducted using the DSM and DTM data produced a maximum average difference of $9.8 \%$ and this means the CHM data were higher than the visual analysis conducted using orthophoto data and this was possibly associated with the high classification results obtained with the CHM data which led to the overclassification of bushes or grass or tree canopy compared to the direct visual method. This difference was observed in clustered areas of bush or grass with very similar spectral characteristics to the canopy cover (Ma 2018). 

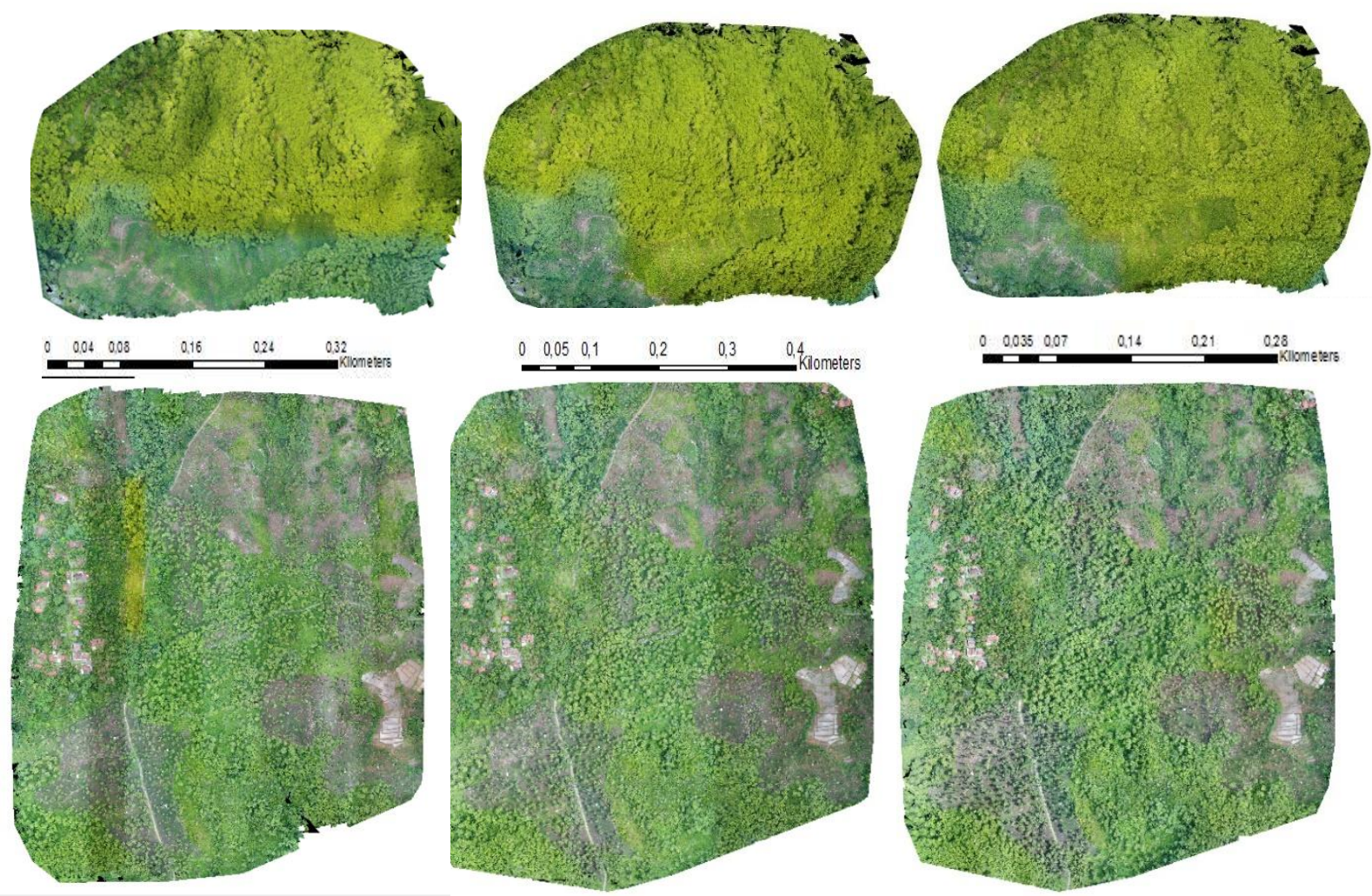

$0 \quad 0050.1$

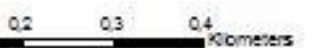

0
0
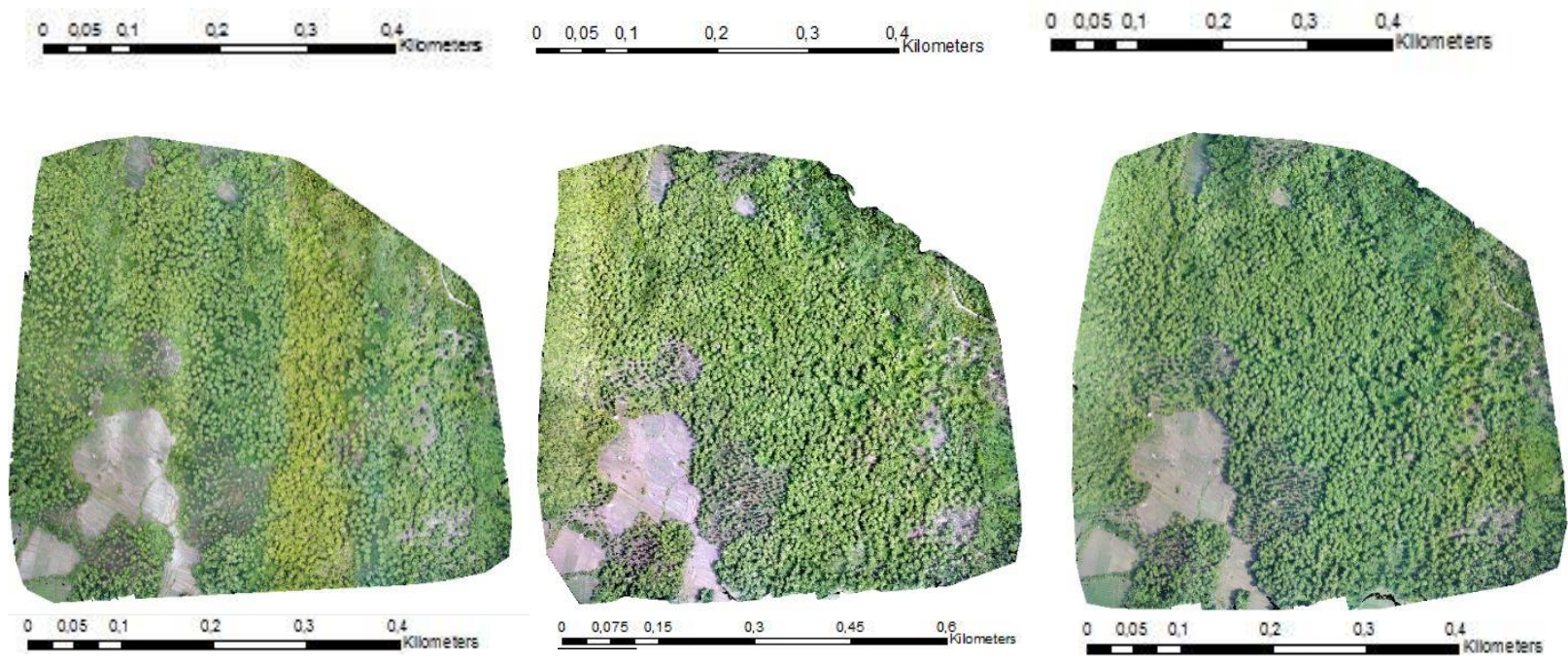

Figure 6 Orthophoto results for (i) age class IV with a flying height of 80 meters, (ii) age class IV with 100 meters, (iii) age class IV with 120 meters, (iv) age class VI with 80 meters, (v) age class VI with 100 meters, (vi) age class VI with 120 meters, (vii) age class VIII with 80 meters, (viii) age class VIII with 100 meters, and (ix) age class VIII with a flying height of 120 meters 

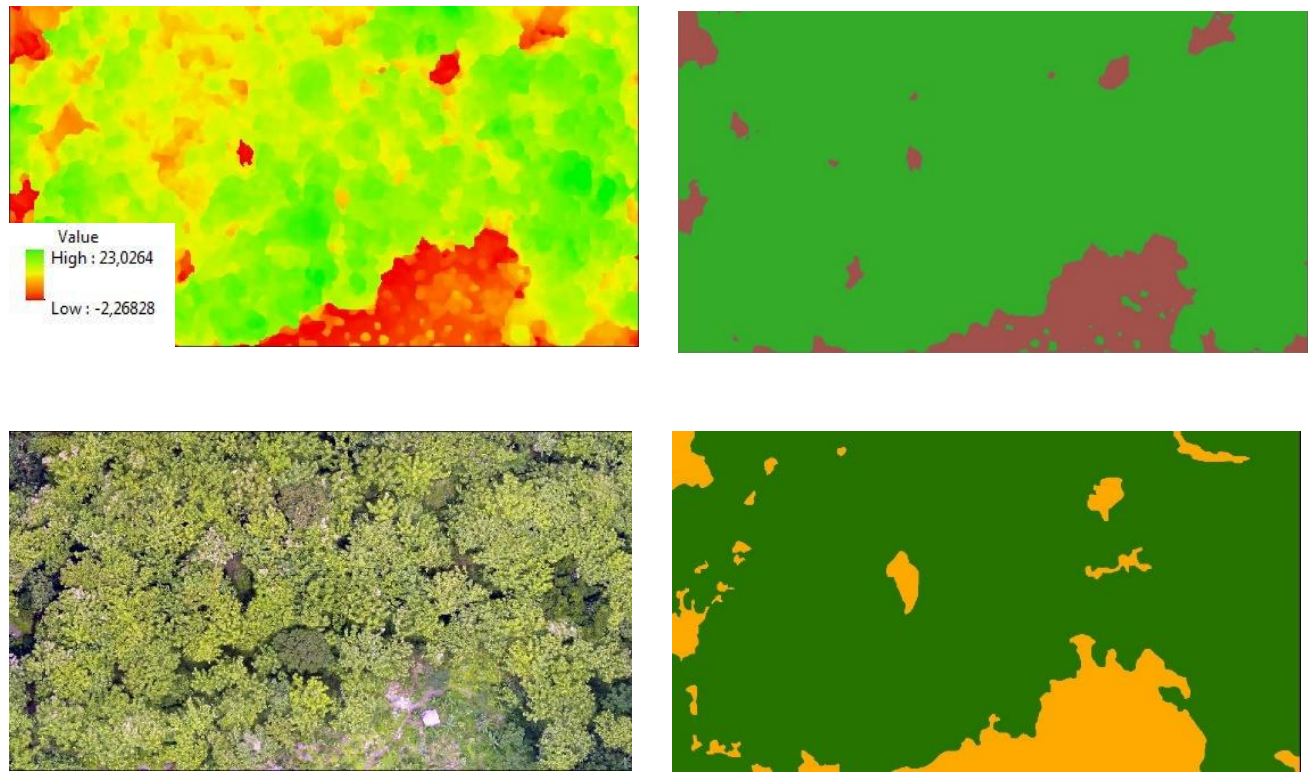

Figure 7 i) CHM data, (ii) cover density classification result, (iii) orthophoto data, and (iv) canopy density of visual analysis results in age class 4 with a flying height of 100 meters.

Table 10. Percentage analysis of canopy density area

\begin{tabular}{|c|c|c|c|c|}
\hline Age class & Height & Data Used & $\%$ & $\begin{array}{c}\text { Differential percent } \\
\text { of canopy } \\
\text { covernya }\end{array}$ \\
\hline \multirow{6}{*}{4} & \multirow{2}{*}{80} & $\mathrm{CHM}$ & 79.3 & \multirow{2}{*}{0.4} \\
\hline & & Orthophoto & 79.7 & \\
\hline & \multirow{2}{*}{100} & $\mathrm{CHM}$ & 89.5 & \multirow{2}{*}{2.8} \\
\hline & & Orthophoto & 86.7 & \\
\hline & \multirow{2}{*}{120} & $\mathrm{CHM}$ & 74.1 & \multirow{2}{*}{4.3} \\
\hline & & Orthophoto & 69.8 & \\
\hline \multirow{6}{*}{6} & \multirow{2}{*}{80} & $\mathrm{CHM}$ & 73.0 & \multirow{2}{*}{8.7} \\
\hline & & Orthophoto & 64.3 & \\
\hline & \multirow{2}{*}{100} & $\mathrm{CHM}$ & 70.2 & \multirow{2}{*}{7.6} \\
\hline & & Orthophoto & 77.8 & \\
\hline & \multirow{2}{*}{120} & $\mathrm{CHM}$ & 80.0 & \multirow{2}{*}{5.9} \\
\hline & & Orthophoto & 74.1 & \\
\hline \multirow{5}{*}{8} & \multirow{2}{*}{80} & CHM & 57.2 & \multirow{2}{*}{9.5} \\
\hline & & Orthophoto & 47.7 & \\
\hline & \multirow{2}{*}{100} & $\mathrm{CHM}$ & 72.3 & \multirow{2}{*}{9.8} \\
\hline & & Orthophoto & 62.5 & \\
\hline & 120 & $\mathrm{CHM}$ & 61.1 & 9.2 \\
\hline
\end{tabular}

\section{CONCLUSION}

Overall, 100 meter flying height has a relationship which was stronger than the 80 meter and 120 meter flying height. This stronger relationship correlates the observed height data with the estimated height and the observed diameter data (D.obs) with the estimated height (T.obs) which indicates a high R2 value and a minimum RMSE value. Furthermore, another analysis in estimating the potential of stands was calculating the percentage of stand density using CHM data by classifying trees above 5 meters and orthophoto data with visual analysis which 
resulted in a maximum percent difference from the canopy cover of $9.8 \%$.

\section{REFERENCES}

Banu TP, Borlea GF, Banu C. 2017. Determination of the forest canopy cover using a low cost commersial drone in a turkey oak and durmast oak stand in the Zarand Mountains, Romania. Journal of Agriculture Science. 49: 12-17.

Birdal AC, Avdan U, Türk T. 2017. Estimating tree heights with images from an unmanned aerial vehicle. Geomatics, Natural Hazards and Risk. 8: 1144-1156. doi: https://doi.org/10.1080/19475705.2017.1300608.

Bottalico F, Chirici G, Giannini R, Mele S, Mura M, Puxeddu M, McRoberts RE, Valbuena R, Travaglini D. 2017. Modeling mediterranean forest structure using airborne laser scanning data. International Journal of Applied Earth Observation and Geoinformation. 57: 145-153. doi: https://doi.org/10.1016/j.jag.2016.12.013.

Carricondoa PM, Vegaa FA, Ramíreza FC, Carrascosab FJM, Ferrerb AG, Porras PFJ. 2018. Assessment of UAV-photogrammetric mapping accuracy based on variation of ground control points. International Journal Applied Earth Observation Geoinformation. 7: $1-10$.

doi: https://doi.org/10.1016/j.jag.2018.05.015.

Eltner A, Sofia G. 2020. Structure from motion photogrammetric technique. Dev Earth Surf Process. 23 January:1-24. doi:10.1016/B978-0-444-641779.00001-1.

Gu Y, Brown JF, Verdin J P, Wardlow B. 2007. A fiveyear analysis of MODIS NDVI and NDWI for grassland drought assessment over the central Great Plains of the United States. Geophysical Research Letters. 34: 1-6. doi: https://doi.org/10.1029/2006gl029127.

Klemas, Victor V. 2015. Coastal and environmental remote sensing from unmanned aerial vehicles: an overview. Journal of Coastal Research. 315: 12601267. doi: https://doi.org/10.2112/jcoastres-d-1500005.1 .

Kusnadi. 2016. Penduga volume dan kualitas tempat tumbuh jati menggunakan citra resolusi sangat tinggi pesawat tidak berawak [Tesis]. Bogor: Institut Pertanian Bogor.

Lynch TB, Rusyidi R. 1999. Distance sampling for forest inventory in Indonesian teak plantations. Forest Ecology and Management. 113: 215-221. doi: https://doi.org/10.1016/S0378-1127(98)00427-7.

Ma Q, Su Y, Guo Q. 2017. Comparison of canopy cover estimations from Airborne LiDAR, Aerial Imagery, and Satellite Imagery. IEEE J Sel Top Appl Earth
Obs Remote Sens. 10(9):4225-4236. doi:10.1109/JSTARS.2017.2711482.

Ma, Q. 2018. Quantifying forest structure parameters and their changes from lidar data and satellite imagery in the sierra nevada [thesis]. Merced: University of California

Micheletti, Natan, Jim H, Chandler, Stuart N, Lane. 2019. Structure from motion (SfM) photogrammetry. British Society for Geomorphology. 1-11. doi: https://doi.org/hdl.handle.net/2134/17493.

Mu Y, Fujii Y, Takata D, Zheng B, Noshita K, Honda K, Ninomiya S, Guo W. 2018. Characterization of peach tree crown by using high-resolution images from an unmanned aerial vehicle. Hortic Res. 5: 74. doi: https://doi.org/10.1038/s41438-018-0097-z.

Mweresa IA, Odera OA, Kuria DN, Kenduiywo BK. 2017. Estimation of tree distribution and canopy heights in ifakara, tanzania using unmanned aerial system (UAS) stereo imagery. American Journal of Geographic Information System. 5: 187-200. doi: https://doi.org/10.5923/j.ajgis.20170605.03.

Ok AO, Ozdarici-Ok A. 2017. Detection of citrus trees from UAV DSMS. Remote Sensing and Spatial Information Sciences, IV-1/W1. 27-34. doi:10.5194/isprs-annals-IV-1-W1-27-2017.

Pôças I, Cunha M, Pereira LS. 2011. Remote sensing based indicators of changes in a mountain rural landscape of Northeast Portugal. Applied Geography. 31: 871-880. doi: https://doi:10.1016/j.apgeog.2011.01.014.

Rokhmana CA. 2015. The Potential of UAV-based Remote sensing for supporting precision agriculture in Indonesia. Procedia Environmental Sciences. 24: 245-253.

doi: https://doi.org/10.1016/j.proenv.2015.03.032.

Sumarna Y. 2008. Pengaruh diameter dan luas tajuk pohon induk terhadap potensi permudaan alam tingkat semai tumbuhan penghasil gaharu jenis karas (aquilaria malaccensis lamk). Jurnal Penelitian Hutan dan Konservasi Alam. 5: 21-27.

Walpole ER. 1995. Pengantar statistika edisi 3. Jakarta: PT. Gramedia Pustaka Utama.

Ye N, Van Leeuwen L, Nyktas P. 2019. Analysing the potential of UAV point cloud as input in quantitative structure modelling for assessment of woody biomass of single trees. International Journal of Applied Earth Observation and Geoinformation. 81: 47-57. doi: https://doi.org/10.1016/j.jag.2019.05.010.

Zarco-Tejada PJ, Diaz-Varela R, Angileri V, Loudjani P. 2014. Tree height quantification using very high resolution imagery acquired from an unmanned aerial vehicle (UAV) and automatic 3D photoreconstruction methods. European Journal of Agronomy. 55: 89-99. doi: https://10.1016/j.eja.2014.01.004. 